\title{
Effects of urea and cowdung on growth and yield of carrot
}

\author{
T. A. Mehedi ${ }^{1}$, M. A. Siddique ${ }^{2}$ and Sonia B. Shahid ${ }^{3}$ \\ ${ }^{1}$ Bangladesh Agricultural Research Institute, Gazipur, ${ }^{2}$ Department of Horticulture and ${ }^{3}$ Department of Biotechnology \\ and Genetic Engineering, Sylhet Agricultural University, Sylhet, Bangladesh. E-mail: tarekbari@yahoo.com
}

\begin{abstract}
A field experiment was carried out to study the effects of inorganic nitrogenous fertilizer and organic cowdung manure on growth and yield of carrot. Three different levels of urea along with three different levels of cowdung were employed in the investigation following randomized complete block design. The result revealed that the application of $150 \mathrm{~kg} \mathrm{~N} \mathrm{ha}^{-1}$ as urea was found suitable for maximum gross and marketable yield $\left(47.35 \mathrm{t} \mathrm{ha}^{-1}\right.$ and $39.0 \mathrm{t} \mathrm{ha}{ }^{-1}$, respectively), while $15 \mathrm{t}$ cowdung ha ${ }^{-1}$ showed better gross and marketable yield (38.13 $\mathrm{t} \mathrm{ha}^{-1}$ and $30.42 \mathrm{t} \mathrm{ha}^{-1}$, respectively). Regarding the combined effect, the combination of $150 \mathrm{~kg} \mathrm{~N} \mathrm{ha}^{-1}$ and $15 \mathrm{t}$ cowdung ha ${ }^{-1}$ resulted in the best performance in gross and marketable yields $\left(51.22 \mathrm{t} \mathrm{ha}^{-1}\right.$ and $43.41 \mathrm{t} \mathrm{ha}^{-1}$, respectively). The net return (TK. $211142 \mathrm{ha}^{-1}$ ) and benefit cost ratio (4.61) were maximum in the treatment combination of $150 \mathrm{~kg} \mathrm{~N} \mathrm{ha}^{-1}$ in the form of urea and $15 \mathrm{t}$ cowdung $\mathrm{ha}^{-1}$.
\end{abstract}

Keywords: Inorganic nitrogenous fertilizer, Manure, Growth, Yield, Carrot

\section{Introduction}

Carrot (Daucus carrota L.) is a highly nutritious cool season root crop. It contains appreciable amount of carotene, thiamin, riboflavin and iron (Sharfuddin and Siddique, 1985). In the year 2009-2010, the area under carrot cultivation was 1,215 hectares, total production of 14,000 metric tons in Bangladesh (BBS, 2010). Rashid (1999) mentioned an average yield of 25 tons per hectare and this yield is relatively low as compared to other carrot producing countries like Israel, Australia, Sweden and Switzerland, where the average per hectare yield is reported to be $58.66,56.37,50.56$ and 57.60 tons respectively (FAO, 2004). Production of carrot in Bangladesh could be increased significantly through increase of per hectare yield. This can be done in many ways, of which the most important one is the judicious application of different fertilizers and manures.

Inorganic fertilizer today holds the key to the success of the crop production system comprising about $50 \%$ of the total production in Bangladesh (BARC, 1997). The yield and yield contributing characters of carrot were influenced by the application of NPK fertilizers. The highest marketable yield was obtained by the application of NPK fertilizers @ $140 \mathrm{~kg}, 40 \mathrm{~kg}$ and $80 \mathrm{~kg} \mathrm{ha}^{-1}$ respectively (Hossain, 2005). Nitrogen @ $200 \mathrm{~kg} \mathrm{ha}^{-1}$ produced the tallest plant, maximum number of leaves, cracked roots, branched roots and fresh shoot weight but nitrogen @ $150 \mathrm{~kg} \mathrm{ha}^{-1}$ produced the maximum root length, root diameter, fresh root weight and the highest yield $53.37 \mathrm{t} \mathrm{ha}^{-1}$ (Haque, 1999). But indiscriminate use of inorganic fertilizer changes physical, chemical and biological properties of soil and creates problem to the environment and health hazards due to the toxic residual effects. Application of different manures (Cowdung/Musturd oil cake) increases the yield of carrot. The highest gross and marketable yields $\left(67.47\right.$ and $\left.60.93 \mathrm{t} \mathrm{ha}^{-1}\right)$ were obtained from the treatment of inorganic fertilizers (290 kg Urea, $225 \mathrm{~kg}$ TSP and $250 \mathrm{~kg} \mathrm{MP}$ ) plus $5 \mathrm{t}$ MOC ha ${ }^{-1}$ (Alom, 2004). Organic manures like cowdung improves soil texture, structure and aeration. Inorganic fertilizer in combination with organic manures also increases the carrot yield (Rumpel et al., 1998, Naher, 1999 and Oleveira et al., 2001). A large number of scientists have studied the effect of inorganic nitrogenous fertilizer on growth and yield of carrot. But no scientist has studied the effect of cowdung on growth and yield of carrot. Therefore, the present study was undertaken to study the effect of inorganic nitrogenous fertilizer and organic cowdung manure on growth \& yield of carrot. 


\section{Materials and Methods}

The experiment was conducted at the Horticultural Farm of Bangladesh Agricultural University, Mymensingh during the period from November 2006 to March 2007. This period is characterized by comparatively low temperature and clear sunshine (SRDI, 1991). The soil was silty loam in texture with a $\mathrm{pH}$ value of 6.55. The organic matter, total nitrogen, phosphorus, potassium content of the experimental plot were $1.68 \%, 0.10 \%, 14 \mathrm{ppm}$ and $0.18 \mathrm{me} / 100 \mathrm{~g}$ soil respectively. The experiment comprised three levels of urea @ 217, 326 \& $435 \mathrm{~kg} \mathrm{ha}^{-1}\left(100,150\right.$ and $200 \mathrm{~kg} \mathrm{~N} \mathrm{ha}^{-1}$, respectively) and three levels of cowdung manure $\left(10,15 \& 20 \mathrm{t}_{\text {cowdung }} \mathrm{ha}^{-1}\right)$. The experiment was laid out in Randomized Complete Block Design with three replications.

Cowdung was applied in each plot and then it mixed with the soil by spading. Nitrogen was applied as urea. top dressing in two equal installments. The first top dressing was done after 30 days of seed sowing and the remaining installment was applied after 30 days of first dose application. The total amounts of TSP @ $150 \mathrm{~kg} \mathrm{ha}^{-1}$ MOP @ $200 \mathrm{~kg} \mathrm{ha}^{-1}$, Gypsum @ $100 \mathrm{~kg} \mathrm{ha}^{-1}$ and $50 \%$ urea were applied as basal dose during final land preparation (BARI, 2005). The rest of urea was applied at 30 days of sowing. Carrot seeds of $3 \mathrm{~kg} \mathrm{ha}^{-1}$ (Rikabdar, 2000) were sown on 31 November, 2006. Before sowing, seeds were soaked in water for 24 hours and then wrapped with a piece of cloth for 5 hours. Three thinning operations were done at 15, 23 and 31 days after sowing of seed to maintain $25 \mathrm{~cm} \times 10 \mathrm{~cm}$ spacing. The experiment plot was kept free from weed infestation, irrigation and other intercultural operations were done when required. The carrots were harvested on 28 February, 2007 after 90 days from seed sowing when the leaves became a pale yellow. Data on different parameters were recorded from ten randomly selected plants in each plot. The data were analyzed statistically and least significant difference (LSD) was used to find out the difference among the mean values (Gomez and Gomez, 1984). The cost of production was analyzed in order to find out the most economic treatment of inorganic nitrogenous fertilizer and cowdung manure combinations.

\section{Results and Discussion}

\section{Effect of Nitrogen}

Different parameters of growth and yield were significantly affected due to different levels of nitrogen except number of leaves plant $^{-1}$ (Table 1). At harvest the highest plant height $(48.06 \mathrm{~cm})$ was obtained when inorganic nitrogenous fertilizer was applied at the rate of $150 \mathrm{~kg} \mathrm{~N} \mathrm{ha}^{-1}$ which was due to the fact that inorganic fertilizer released nutrients quickly and supplied adequate plant nutrients for better vegetative growth of the carrot plant. Sharangi and Paria (1995) reported that application of NPK fertilizer increased plant height in carrot. The result revealed that the maximum length of root was achieved with the application of $150 \mathrm{~kg} \mathrm{~N} \mathrm{ha}^{-1}$ which was followed by $200 \mathrm{~kg} \mathrm{~N} \mathrm{ha}^{-1}$. The similar trend of response was observed in the case of diameter of root, fresh weight of roots, gross yield and marketable yield. However, the highest gross $\left(47.35 \mathrm{t} \mathrm{ha}^{-1}\right)$ and marketable yield $\left(39.00 \mathrm{t} \mathrm{ha}^{-1}\right)$ were obtained from $150 \mathrm{~kg}$ $\mathrm{N} \mathrm{ha}^{-1}$, and which results might be due to the cumulative positive effects of length of root, diameter of root and fresh weight of root plant ${ }^{-1}$. The increase in gross yield and marketable yield due to application of 150 $\mathrm{kg} \mathrm{N} \mathrm{ha}^{-1}$ were $115.9 \%$ and $115.3 \%$ higher over those with $100 \mathrm{~kg} \mathrm{~N} \mathrm{ha}^{-1}$. This result indicated that the application of $150 \mathrm{~kg} \mathrm{~N}^{-1}$ might have significant contribution to proper growth and development of root through optimum nutrient uptake by the crop plants. Polach (1982) and Abdel Razik (1996) also reported significant effects of $\mathrm{N}$ levels on carrot. The lowest performance of yield attributes was recorded for 100 $\mathrm{kg} \mathrm{N} \mathrm{ha}^{-1}$ as it did not fulfill the requirement of the crops resulting in poor growth and development of the root. Regarding root characteristics, it was indicated the maximum percentage of branched roots was observed in $200 \mathrm{~kg} \mathrm{~N}^{-1}$ which was supported by the findings of Orphans and Krentos (1988). The percentage of cracked root and rotten roots showed increasing trend with the increasing levels of $\mathrm{N} \mathrm{ha}^{-1}$. Bose and Som (1990) also observed similar response. 
Table 1. Effect of nitrogen on growth and yield of Carrot

\begin{tabular}{|l|c|c|c|c|c|c|c|c|c|c|c|}
\hline $\begin{array}{l}\text { Nitrogen } \\
\text { levels } \\
\left(\mathrm{kg} \mathrm{ha}^{-1}\right)\end{array}$ & $\begin{array}{c}\text { Plant } \\
\text { height } \\
(\mathrm{cm})\end{array}$ & $\begin{array}{c}\text { No. of } \\
\text { leaves } \\
\text { plant-1 }\end{array}$ & $\begin{array}{c}\text { Length } \\
\text { of root } \\
(\mathrm{cm})\end{array}$ & $\begin{array}{c}\text { Diameter } \\
\text { of root } \\
(\mathrm{cm})\end{array}$ & $\begin{array}{c}\text { Fresh wt. } \\
\text { of leaves } \\
\left.\text { plant-1 }^{-1} \mathrm{~g}\right)\end{array}$ & $\begin{array}{c}\text { Fresh wt. } \\
\text { of root } \\
\text { plant }^{-1}(\mathrm{~g})\end{array}$ & $\begin{array}{c}\text { Branched } \\
\text { root (\%) }\end{array}$ & $\begin{array}{c}\text { Cracked } \\
\text { root (\%) }\end{array}$ & $\begin{array}{c}\text { Rotten } \\
\text { root (\%) }\end{array}$ & $\begin{array}{c}\text { Gross yield } \\
\text { of root } \\
\left(\mathrm{t} \mathrm{ha}^{-1}\right)\end{array}$ & $\begin{array}{c}\text { Marketable } \\
\text { yield } \\
(\mathrm{t} \mathrm{ha-1})\end{array}$ \\
\hline 100 & 45.32 & 10.43 & 13.27 & 3.50 & 41.36 & 54.91 & 10.53 & 4.57 & 1.97 & 2.19 & 1.81 \\
\hline 150 & 48.06 & 10.57 & 15.09 & 4.39 & 76.94 & 118.24 & 6.87 & 7.09 & 3.14 & 4.73 & 3.90 \\
\hline 200 & 47.16 & 10.48 & 14.07 & 4.05 & 60.08 & 90.27 & 13.84 & 11.53 & 5.18 & 3.61 & 2.49 \\
\hline $\mathrm{CV}(\%)$ & 5.27 & 4.68 & 5.07 & 3.83 & 4.76 & 4.65 & 4.91 & 3.01 & 7.86 & 4.54 & 5.17 \\
\hline $\mathrm{LSD}_{0.05}$ & 0.58 & 0.153 & 0.159 & 0.082 & 0.573 & 2.229 & 0.279 & 0.126 & 0.147 & 0.487 & 0.263 \\
\hline
\end{tabular}

\section{Effect of cowdung}

Different parameters of growth and yield were significantly affected due to different levels of cowdung manure (Table 2). The organic matter, total nitrogen, phosphorus, potassium content of the experimental plot were $1.68 \%, 0.10 \%, 14 \mathrm{ppm}$ and $0.18 \mathrm{me} / 100 \mathrm{~g}$ soil respectively. Organic manure increased the water holding capacity of the soil, kept soil loose and friable which are desirable for carrot. The highest gross yield (38.13t ha $\mathrm{ha}^{-1}$ and marketable yield $\left(30.42 \mathrm{t} \mathrm{ha}^{-1}\right)$ were obtained from the application of cowdung@15 t ha ${ }^{-1}$ which was followed by cowdung @ $20 \mathrm{t} \mathrm{ha}^{-1}$. This result indicated that the application of $15 \mathrm{t}$ cowdung ha ${ }^{-1}$ might have significant contribution to proper growth and development of root through optimum nutrient uptake by the crop plants. The lowest performance of yield attributes was recorded due to application of $10 \mathrm{t}$ cowdung ha ${ }^{-1}$. Probably the application of $10 \mathrm{t}_{\text {cowdung }} \mathrm{ha}^{-1}$ did not fulfill the requirement of the crops which resulted in poor growth and development of the root and ultimately exerted the lowest performance. Regarding root characteristics, with the increase in the rate of cowdung the percentage of branched root and rotten roots were increased. That is why with the application of cowdung @ $20 \mathrm{t} \mathrm{ha}^{-1}$ the percentage of branched root and rotten roots were increased which reduced the marketable yield.

\section{Table 2. Effect of cowdung on growth and yield of carrot}

\begin{tabular}{|c|c|c|c|c|c|c|c|c|c|c|c|}
\hline $\begin{array}{l}\text { Cowdung } \\
\text { levels } \\
\left(\mathrm{t} \mathrm{ha}^{-1}\right)\end{array}$ & $\begin{array}{c}\text { Plant } \\
\text { height } \\
(\mathrm{cm})\end{array}$ & $\begin{array}{c}\text { No. of } \\
\text { leaves } \\
\text { plant }^{-1}\end{array}$ & $\begin{array}{c}\text { Length } \\
\text { of root } \\
(\mathrm{cm})\end{array}$ & $\begin{array}{c}\text { Diameter } \\
\text { of root } \\
(\mathrm{cm})\end{array}$ & $\begin{array}{c}\text { Fresh wt. } \\
\text { of leaves } \\
\text { plant }^{-1}(\mathrm{~g})\end{array}$ & $\begin{array}{c}\text { Fresh wt. } \\
\text { of root } \\
\text { plant }^{-1}(\mathrm{~g})\end{array}$ & $\begin{array}{c}\text { Branched } \\
\text { root (\%) }\end{array}$ & $\begin{array}{c}\text { Cracked } \\
\text { root (\%) }\end{array}$ & $\begin{array}{c}\text { Rotten } \\
\text { root } \\
(\%)\end{array}$ & $\begin{array}{c}\text { Gross yield } \\
\text { of root } \\
\left(\mathrm{t} \mathrm{ha}^{-1}\right)\end{array}$ & $\begin{array}{c}\text { Marketable } \\
\text { yield } \\
\left(\mathrm{t} \mathrm{ha}^{-1}\right)\end{array}$ \\
\hline 10 & 46.09 & 10.15 & 13.80 & 3.84 & 52.86 & 79.09 & 9.68 & 7.70 & 2.76 & 31.66 & 24.94 \\
\hline 15 & 47.55 & 10.83 & 14.47 & 4.14 & 65.38 & 95.31 & 9.84 & 6.89 & 3.51 & 38.13 & 30.42 \\
\hline 20 & 46.89 & 10.49 & 14.16 & 3.96 & 60.14 & 89.06 & 11.73 & 8.59 & 4.02 & 35.63 & 26.71 \\
\hline $\mathrm{CV}_{(\%)}$ & 5.27 & 4.68 & 5.07 & 3.83 & 4.76 & 4.65 & 4.91 & 3.01 & 7.86 & 4.54 & 5.17 \\
\hline $\mathrm{LSD}_{0.05}$ & 0.58 & 0.153 & 0.159 & 0.082 & 0.573 & 2.229 & 0.279 & 0.126 & 0.147 & 0.487 & 0.263 \\
\hline
\end{tabular}

\section{Combined effect of nitrogen and cowdung manure}

The interaction effect of inorganic nitrogen applied as urea and cowdung manure had significant effect in most of the characters studied (Table 3$)$. The highest length of root $(15.67 \mathrm{~cm})$ was obtained from the treatment combination of $150 \mathrm{~kg} \mathrm{~N} \mathrm{ha}^{-1}$ and cowdung $15 \mathrm{t} \mathrm{ha}^{-1}$, whereas the lowest length of root (13.17 $\mathrm{cm}$ ) was produced by the treatment combination of $100 \mathrm{~kg} \mathrm{~N} \mathrm{ha}^{-1}$ and cowdung $10 \mathrm{t} \mathrm{ha}^{-1}$. The treatment combination of $150 \mathrm{~kg} \mathrm{~N}^{-1}$ and $15 \mathrm{t}$ cowdung ha ${ }^{-1}$ produced the highest root fresh weight $127.98 \mathrm{~g}$ followed by $118.24 \mathrm{~g}$ and $95.31 \mathrm{~g}$ from $150 \mathrm{~kg} \mathrm{~N}^{-1}$ and $15 \mathrm{t}^{-1}$ cowdung ha ${ }^{-1}$. The inorganic nitrogen fertilizer plus organic fertilizer produced the thickest root $(4.59 \mathrm{~cm})$ followed by $4.39 \mathrm{~cm}$ and $4.14 \mathrm{~cm}$ from inorganic $150 \mathrm{~kg} \mathrm{~N} \mathrm{ha}^{-1}$ and organic $15 \mathrm{t}$ cowdung ha ${ }^{-1}$, respectively. The results are in agreement with Prarraga et al., (1995) who reported that the application of organic matter with NPK increased the diameter of carrot root. The lowest branched root (5.63\%), cracked root (6.72 \%) and rotten root (3.13\%) were obtained from the treatment combination of $150 \mathrm{~kg} \mathrm{~N}^{-1}$ and $15 \mathrm{t}$ cowdung ha- ${ }^{-1}$. As a result, the highest gross yield of $\left(51.22 \mathrm{t} \mathrm{ha}^{-1}\right)$ and marketable yield $\left.43.41 \mathrm{t} \mathrm{ha}^{-1}\right)$ were recorded from the combination 
of $150 \mathrm{~kg} \mathrm{~N} \mathrm{ha}^{-1}$ and $15 \mathrm{t}$ cowdung ha ${ }^{-1}$. The maximum diameter and fresh weight of root, achieved in 150 $\mathrm{kg} \mathrm{N} \mathrm{ha}^{-1}$ and $15 \mathrm{t}$ cowdung ha ${ }^{-1}$ might be attributed to the highest gross and marketable yields of carrot. The lowest gross $\left(19.40 \mathrm{t} \mathrm{ha}^{-1}\right)$ and marketable yield $\left(16.9 \mathrm{t} \mathrm{ha}^{-1}\right)$ obtained due to the combined effects of $100 \mathrm{~kg} \mathrm{~N} \mathrm{ha}^{-1}$ and $10 \mathrm{t}$ cowdung ha ${ }^{-1}$. Kropisz (1992) mentioned that yield of carrot increased by the application of manures in addition to NPK fertilizer. Result of the present study is also supported by the findings of Vieira et al., (1998) who obtained the highest yield of carrot with $P$ and poutry house litter. It might be due to the fact that inorganic nitrogenous fertilizer supplied readily available plant nutrients for quick root development.

Table 3. Combined effect of nitrogen \& cowdung manure on growth and yield of carrot

\begin{tabular}{|c|c|c|c|c|c|c|c|c|c|c|c|}
\hline $\begin{array}{l}\text { Treatment } \\
\text { interaction } \\
\text { (Nitrogen } x \\
\text { Cowdung) }\end{array}$ & $\begin{array}{l}\text { Plant } \\
\text { height } \\
\text { (cm) }\end{array}$ & $\begin{array}{l}\text { No. of } \\
\text { leaves } \\
\text { plant }^{-1}\end{array}$ & $\begin{array}{l}\text { Length } \\
\text { of root } \\
(\mathrm{cm})\end{array}$ & $\begin{array}{c}\text { Diameter } \\
\text { of root } \\
\text { (cm) }\end{array}$ & $\begin{array}{l}\text { Fresh wt. } \\
\text { of leaves } \\
\text { plant }^{-1}(\mathrm{~g})\end{array}$ & $\begin{array}{l}\text { Fresh wt. } \\
\text { of root } \\
\text { plant }^{-1}(\mathrm{~g})\end{array}$ & $\begin{array}{c}\text { Branched } \\
\text { root (\%) }\end{array}$ & $\begin{array}{l}\text { Cracked } \\
\text { root (\%) }\end{array}$ & $\begin{array}{l}\text { Rotten } \\
\text { root (\%) }\end{array}$ & $\begin{array}{c}\text { Gross } \\
\text { yield of } \\
\text { root } \\
\left(\mathrm{t} \mathrm{ha}^{-1}\right)\end{array}$ & $\begin{array}{c}\text { Marketable } \\
\text { yield } \\
\left(\mathrm{t} \mathrm{ha}^{-1}\right)\end{array}$ \\
\hline $\mathrm{N}_{1} \mathrm{C}_{1}$ & 44.14 & 9.83 & 13.17 & 3.34 & 35.02 & 48.79 & 8.33 & 3.50 & 1.43 & 19.40 & 16.91 \\
\hline $\mathrm{N}_{1} \mathrm{C}_{2}$ & 46.50 & 10.93 & 13.41 & 3.72 & 46.52 & 60.25 & 11.25 & 4.15 & 2.21 & 24.10 & 19.86 \\
\hline $\mathrm{N}_{1} \mathrm{C}_{3}$ & 45.33 & 10.51 & 13.23 & 3.46 & 42.55 & 55.70 & 12.00 & 6.04 & 2.28 & 22.28 & 17.64 \\
\hline $\mathrm{N}_{2} \mathrm{C}_{1}$ & 46.35 & 10.38 & 14.58 & 4.23 & 69.90 & 106.31 & 6.53 & 7.58 & 2.78 & 42.68 & 35.28 \\
\hline $\mathrm{N}_{2} \mathrm{C}_{2}$ & 48.81 & 10.78 & 15.67 & 4.59 & 83.26 & 127.98 & 5.63 & 6.72 & 3.13 & 51.22 & 43.41 \\
\hline $\mathrm{N}_{2} \mathrm{C}_{3}$ & 49.00 & 10.56 & 15.05 & 4.34 & 77.68 & 120.42 & 8.45 & 7.00 & 3.50 & 48.16 & 38.50 \\
\hline $\mathrm{N}_{3} \mathrm{C}_{1}$ & 47.80 & 10.24 & 13.67 & 3.96 & 53.67 & 82.20 & 14.17 & 12.03 & 4.08 & 32.88 & 22.63 \\
\hline $\mathrm{N}_{3} \mathrm{C}_{2}$ & 47.33 & 10.79 & 14.33 & 4.11 & 66.37 & 97.70 & 12.63 & 9.81 & 5.18 & 39.08 & 28.00 \\
\hline $\mathrm{N}_{3} \mathrm{C}_{3}$ & 46.36 & 10.42 & 14.20 & 4.09 & 60.20 & 90.89 & 14.73 & 12.75 & 6.28 & 36.48 & 23.99 \\
\hline CV (\%) & 5.27 & 4.68 & 5.07 & 3.83 & 4.76 & 4.65 & 4.91 & 3.01 & 7.86 & 4.54 & 5.17 \\
\hline $\mathrm{LSD}_{0.05}$ & 1.005 & 0.265 & 0.275 & 0.143 & 0.992 & 3.861 & 0.484 & 0.219 & 0.255 & 0.844 & 0.820 \\
\hline
\end{tabular}

$\mathrm{N}_{1}=100 \mathrm{~kg} \mathrm{~N} \mathrm{ha}^{-1}, \mathrm{~N}_{2}=150 \mathrm{~kg} \mathrm{~N} \mathrm{ha}^{-1}, \mathrm{~N}_{3}=200 \mathrm{~kg} \mathrm{~N} \mathrm{ha}^{-1}$ and $\mathrm{C}_{1}=10 \mathrm{t}$ cowdung ha ${ }^{-1}, \mathrm{C}_{2}=15 \mathrm{t}$ cowdung ha $^{-1}$ and $\mathrm{C}_{3}=15 \mathrm{t}$ cowdung ha ${ }^{-1}$

\section{Analysis of cost of production}

The cost and return analysis has been presented in Table 4. The treatment combination of $150 \mathrm{~kg} \mathrm{~N}^{-1}$ and cowdung manure $15 \mathrm{t} \mathrm{ha}^{-1}$ gave the highest net return (TK.211142 ha ${ }^{-1}$ ), followed by $150 \mathrm{~kg} \mathrm{~N} \mathrm{ha}^{-1}$ and cowdung $20 \mathrm{t} \mathrm{ha}^{-1}$ (TK 1,73755). But the lowest net return (TK.43530 ha ${ }^{-1}$ ) was obtained from the treatment combination of $100 \mathrm{~kg} \mathrm{~N} \mathrm{ha}^{-1}$ and $20 \mathrm{t}_{\text {cowdung }} \mathrm{ha}^{-1}$. The benefit cost ratio (BCR) was found to be the highest (4.61) in the treatment combination of $150 \mathrm{~kg} \mathrm{~N}^{-1}$ and cowdung manure $15 \mathrm{t} \mathrm{ha}^{-1}$.

Table 4. Cost and return analysis of carrot due to nitrogen and cowdung treatment

\begin{tabular}{|c|c|c|c|c|c|}
\hline $\begin{array}{l}\text { Treatment interaction } \\
\text { (Nitrogen } \times \text { Cowdung) }\end{array}$ & $\begin{array}{l}\text { Marketable } \\
\text { yield }\left(\mathrm{t} \mathrm{ha}^{-1}\right)\end{array}$ & $\begin{array}{l}\text { Gross return } \\
\left(\text { TK. ha }{ }^{-1}\right)\end{array}$ & $\begin{array}{c}\text { Total cost of } \\
\text { production (TK. } \\
\text { ha }^{-1} \text { ) }\end{array}$ & $\begin{array}{l}\text { Net return (TK. } \\
\left.\mathrm{ha}^{-1}\right)\end{array}$ & $\begin{array}{c}\text { Benefit cost ratio } \\
\text { (BCR) }\end{array}$ \\
\hline $\mathrm{N}_{1} \mathrm{C}_{1}$ & 17.22 & 103320 & 54703 & 48617 & 1.89 \\
\hline $\mathrm{N}_{1} \mathrm{C}_{2}$ & 20.76 & 124560 & 57769 & 66791 & 2.16 \\
\hline $\mathrm{N}_{1} \mathrm{C}_{3}$ & 18.18 & 109080 & 60836 & 48244 & 1.79 \\
\hline $\mathrm{N}_{2} \mathrm{C}_{1}$ & 37.24 & 223440 & 55433 & 168007 & 4.03 \\
\hline $\mathrm{N}_{2} \mathrm{C}_{2}$ & 44.94 & 269640 & 58498 & 211142 & 4.61 \\
\hline $\mathrm{N}_{2} \mathrm{C}_{3}$ & 39.22 & 235320 & 61265 & 173755 & 3.82 \\
\hline $\mathrm{N}_{3} \mathrm{C}_{1}$ & 23.35 & 140100 & 56162 & 83938 & 2.49 \\
\hline $\mathrm{N}_{3} \mathrm{C}_{2}$ & 29.03 & 174180 & 59228 & 114952 & 2.94 \\
\hline $\mathrm{N}_{3} \mathrm{C}_{3}$ & 25.33 & 15198 & 62295 & 89685 & 2.44 \\
\hline
\end{tabular}

Note: Sale of carrot @ TK.6000 $\mathrm{t}^{-1}$, Gross return= Marketable yield t ha ${ }^{-1} \times$ TK.6000/; BCR=Gross return $\div$ total cost of production; $N_{1}=100 \mathrm{~kg} \mathrm{~N} \mathrm{ha}^{-1}, \mathrm{~N}_{2}=150 \mathrm{~kg} \mathrm{~N} \mathrm{ha}^{-1}, \mathrm{~N}_{3}=200 \mathrm{~kg} \mathrm{~N} \mathrm{ha}^{-1} ; \mathrm{C}_{1}=10 \mathrm{t}$ cowdung ha ${ }^{-1}$, $\mathrm{C}_{2}=15 \mathrm{t}$ cowdung ha ${ }^{-1}$ and $\mathrm{C}_{3}=15 \mathrm{t}$ cowdung ha ${ }^{-1}$. 


\section{Conclusion}

From the production as well as economic points of view a combination of $150 \mathrm{~kg} \mathrm{~N}^{-1}$ with $15 \mathrm{t}$ cowdung $\mathrm{ha}^{-1}$ may be suggested for maximizing carrot production under BAU farm condition. Since the present study was conducted in only one agro ecological zone, further investigations are needed to be carried out in other AEZ'S of Bangladesh.

\section{References}

Abdel Razik, A.H. 1996. Effect of nitrogen fertilizer levels and gibberellic acid concentration on carrot yield in sandy soils. Alexandria J. Agril. Res., 41(2): 379 - 388.

Alom, A. 2004. Effect of organic and inorganic fertilizers on growth and yield of carrot. MS Thesis, Department of Horticulture, Bangladesh Agricultural University, Mymensingh. p. 86.

BARI. 2005. Homestead Vegetable Production: Training Manual. On-Farm Research Division. Bangladesh Agricultural Research Institute, Joydevpur, Gazipur. p. 94.

BBS. 2010. Yearbook of Agricultural Statistics of Bangladesh. Bangladesh Bureau of Statistics, Ministry of Planning, Dhaka, Bangladesh. p. 124.

Bose, T.K and Som, M.G. 1990. Vegetable Crops in India. Naya Prokash, Calcutta, India. pp. 408-442.

BARC. 1997. Fertilizer Recommendation Guide. Bangladesh Agricultural Research Council, Farmgate, Dhaka, 196 pp.

FAO. 2004. Production Year Book. Food and Agricultural Organization, Rome, Italy, 61(2): 99-111.

Fujime, Y., Okuda, N., Nishio, T. and Meng, G. Y. 2001. Utilization of excreta ashes in vegetable cultivation. Scientific Reports of the Kyoto Prefetural University, Human Env. And Agric., 53 : 35-38

Gomez, K.A. and Gomez, A.A. 1984. Statistical Procedures for Agricultural Research (2 ${ }^{\text {nd }}$ ed.). Wiley-Inter Science Publication, John Wiley and Sons, New York. p. 680.

Haque, M.M. 1999. Effect of spacing and mulching on the growth and yield of carrot. MS Thesis, Department of Horticulture, Bangladesh Agricultural University, Mymensingh. Pp. 31-56.

Hossain, M. 2005. Effect of NPK fertilizers on growth and yield of carrot. MS Thesis, Department of Horticulture, Bangladesh Agricultural University, Mymensingh. pp. 31-57.

Kropisz, A. 1992. Influence of fertilization with compost on yield of vegetables and their content of mineral elements. Annals of Warsaw Agril. Univ., 16: 9-13.

Naher, N.A. 1999. Effect of fertilizer management practices and irrigation on production of potato. MS Thesis, Department of Horticulture, BAU, Mymensingh, $88 \mathrm{pp}$.

Oliveira, A.P., Espinola, J.E.F., Araujo, J.S. and Costa, C.C. 2001. Root production in carrots treated with earthworm compost and mineral fertilizer. Hort. Brasileira, 19(1):77-88.

Orphanos, P.I. and V.D. Krentos. 1988. Nitrogen and phosphorus fertilizing of carrots. Tech.Bull. Agril. Res. Inst., Cyprus, 99:8p [Cited from Hort. Abstr., 60(2):1169, 1990].

Polach, J. 1982. Effect of fertilization on carrot yield and quality.Bull.Vyzkumnya Slechtite Isky.Ustav Zelinarsky O Iomuc. Czechoslovaki, 25/26: 119-127 [Cited from Hort. Abstr., 53 (7):508, 1983].

Rashid, M.M. 1999.Shabjee Biggan (In Bengali). $2^{\text {nd }}$ Ed. Rashid Publishing House, 94, Old DOHS, Dhaka-1206.pp.498-503.

Rikabdar, F.H. 2000. Adhunik Upaya Shabje Chash (in Bengali). Agriculture Information Service, Dhaka: Khamarbari, pp. 29-30.

Rumpel, J., Jakubczyk, H., Lata, B., Sadowski, A. and whitehead, O. 1998. Effect of long term organic and mineral fertilization on soil properties and development of tomato, carrot and onion. A seminar on ecological aspects of nutrition and alternatives for hervicides in horticulture, Warszawa, Poland. 10-15 June, 1997, pp. 63-64.

Sharangi, A.B. and Paria, N.C. 1995. Growth, yield and qualitative responses by carrot to varying levels of nitrogen and potassium. Hort. J., 8(2) : 161-164.

Sharfuddin,A.F.M. and Siddique, M.A. 1985. Shabjee Biggan. $1^{\text {st }}$ Edn.Mrs. Hasina Akthar Beauty, Bangladesh Agricultural University,Mymensingh. p. 11.

SRDI. 1991. Land and Soil Resource Utilization Guide: Mymensingh Sadar Thana, Mymensingh. (In Bangali,). SRDI, Ministry of Agricultural, Dhaka, Bangladesh. p. 3.

Vieira, M.C., Casali, V.W.D., Cardoso, A.A. and osquim, P.R. 1998. Perunian carrot growth and yield as function of phosphate fertilization and use of poultry house litter. Hort. Brasileira, 16(1): 68-73. 